\title{
PRAKSEOLOGIA W COACHINGU JAKO INTERAKTYWNYM PROCESIE ODKRYWANIA ZASOBÓW I MOŻLIWOŚCI COACHEE
}

\begin{abstract}
Streszczenie. Prakseologia jako praktyka czynu zainicjowana przez francuskiego intelektualistę Alfreda Espinasa i Aleksandra Bogdanowa (Malinowskiego) to nauka o wszelkich sprawnościach ludzkiej działalności. Jak piszą Tadeusz Kotarbiński oraz Tadeusz Pszczołowski: będąc metodologią ogólną, której działania koncentrują się wokół wyodrębniania i systematyzacji bogactwa różnorodnych form działania, prakseologia staje się także próbą ich usprawnienia i upraktycznienia. To upraktycznienie zakłada analizę rzeczywistości oraz przyjęcie pewnych sposobów obchodzenia się z zasobami możliwości. Zatem prakseologia już jako tektologia każe nazywać wszelkie możliwe działanie organizowaniem lub łączeniem w całość bogatego i skomplikowanego spiętrzenia zasobów. Jednym z efektów tego spiętrzenia powinna być gwarancja dopasowania środków do założonego celu, a zarazem towarzysząca temu okazja uzyskania optimum rezultatu.
\end{abstract}

Artykuł pokazuje, że elementy prakseologiczne uobecniają się współcześnie w procesie coachingowym. Dzięki temu coaching jako aktywna forma komunikacji dialogicznej jest obecnie jedną z najskuteczniejszych form wspierania drugiego człowieka w samodzielnym odkrywaniu własnych zdolności oraz potencjału zasobów pozwalających sprawnie realizować wyznaczane cele.

Słowa kluczowe: prakseologia, Tadeusz Kotarbiński, Alfred Espinas, Aleksander Bogdanow, tektologia, interaktywny proces, dialog, coaching, Coachee

1. Wstęp. 2. Definicje coachingu. 3. Prakseologia i jej wykorzystanie w coachingu.

4. Zakończenie.

\section{WSTĘP}

Zgodnie z zamysłem Philippe’a Rosinskiego, doświadczonego coacha kadry kierowniczej, a zarazem wybitnego autorytetu w zakresie team coachingu i leadership coachingu, „coaching nie »urodził się« na 
uczelni, [lecz - A.M.] wyłonił się z praktyki"1. Taki coachingowy, praktyczny styl pracy powinien jego zdaniem przeniknąć w struktury społeczeństwa, by stać się „życiową drogą rozwoju”2.

Biorąc pod uwagę przytoczone słowa, podejmuję próbę wskazania miejsca prakseologii w procesie coachingowym. Prakseologię ujmuję jako aktywność, która uwzględnia kolejno momenty: diagnozy, prognozy, planowania lub programowania, praktycznej realizacji zamierzeń oraz ewaluacji efektów - stając się w ten sposób istotnym składnikiem fazy praksis procesu. Jednak ze względu na wielość i niejednoznaczność możliwych wykładni coachingowej formy pracy, swoje rozważania rozpoczynam od dookreślenia pojęcia coachingu i procesu coachingowego.

\section{DEFINICJE COACHINGU}

Najczęściej mówi się, że coaching jest formą stałego i kompleksowego wzmacniania przez coacha swojego rozmówcy. Częstokroć w sposób bezpośredni, domenę tę określa się także mianem inspirującej pozbawionej doradczej formy - relacji, która pomaga w przeprowadzeniu trwałej zmiany (International Coaching Community); wspomaga budowę pożądanych postaw, bądź pozwala rozwinąć nowe strategie zachowań 4 .

Liczna grupa specjalistów parających się coachingiem ujmuje tę profesję w kategoriach sztuki zadawania cennych pytań (Tony

1 P. Rosinski, Globalny coaching. Podejście zintegrowane, tłum. z ang. A. Niedzieska, P. Niedzieski, Warszawa 2011, XVI-XVII.

2 Tamże, XVI.

3 Zob. www.iccpoland.pl [dostęp: 25.03.2018].

4 Por. Moc coachingu. Poznaj narzędzia rozwijajq̨ce umiejętności i kompetencje osobiste, red. M. Wilczyńska, M. Nowak, J. Kućka i in., Gliwice 2013, 19. Zob. Wprowadzenie. Jak prosperować w świecie VUCA. Dlaczego przywództwo strategiczne jest dzisiaj tak ważne?, w: S. Krupp, P.J.H. Schoemaker, Zwycięskie strategie. Jak liderzy tworzą przyszłe sukcesy, tłum. z ang. M. Lipa, Warszawa 2016, 11-29. 
Stoltzfus) $)^{5}$. Inni eksperci dostrzegają w niej matrycę wspólpracy i doskonalenia działań oraz cyzelowania efektywności (Jenny Rogers) ${ }^{6}$. Jeszcze inni praktycy tej formy wspierania twierdzą, że coaching jest wzorcowym procesem samodzielnego uczenia się umiejętności wykorzystywania możliwości w atmosferze indywidualnego wsparcia ze strony osoby pobudzającej do podejmowania określonych wyzwań i stymulującej procesy rozwoju (Gerard O'Donovan, Noble Manhattan Coaching) ${ }^{7}$.

Wiele organizacji kojarzy coaching z dyscyplinami pokrewnymi, takimi jak zarządzanie, doradztwo zawodowe, psychoterapia lub szkolenia. Wymienione dziedziny mają dłuższą historię zastosowań (Barbara Zych, Mary Berth O’Neil) ${ }^{8}$. Inni postrzegają coaching $\mathrm{w}$ wymiarze interaktywnego procesu zgłębiania wiedzy. Nierzadko zdarza się także postrzegać coaching w surowych kategoriach rozwijającej się relacji zawodowej (International Coach Federation) ${ }^{9}$. Esencją coachingowego procesu jest zawsze - wsparte permanentną, świadomą przemianą - uczenie się siebie i poznawanie siebie, poprzez kreatywne rozpoznawanie własnych potrzeb ${ }^{10}$. Proces, w którym osoba coachowana wydobywa z siebie wiedzę o sobie samej, polega głównie na uświadamianiu sobie przez tę osobę (Coachee) własnych zasobów i możliwości.

Aby te pierwotnie, dotąd niedostrzegane przez Coachee (Klienta, Podopiecznego) zasoby i możliwości Coachee mógł w sobie odkryć,

5 Zob. T. Stoltzfus, Sztuka zadawania pytań w coachingu. Jak opanować największą umiejętność coacha?, Cieszyn 2012, 8.

6 Por. J. Rogers, Coaching. Podstawy efektywności, tłum. z ang. K. Konarowska, D. Porażka, Gdańsk 2010, 14.

7 Zob. G. O'Donovan, A Coach's Story: revealing insights into life as a professional coach, Book Shaker 2011.

8 Zob. M.B. O’Neil, Coaching dla kadry menadżerskiej. Siła i wrażliwość coacha w systemowym podejściu do problemów w zarządzaniu, Poznań 2005.

9 Zob. icf.org.pl [dostęp: 25.03.2018].

10 Por. M. Bennewicz, Coaching, kreatywność, zabawa. Narzędzia rozwoju dla pasjonatów i profesjonalistów, Olsztyn 2014, 63. 
Coach pracuje nad elementami zmiany, utrzymania bądź rozwoju. W takiej sytuacji coaching jako proces, nade wszystko staje się konstruktywnym dialogiem założonym w aktywnej formie komunikacji równoległej. Tak rozumiana konwersacja absolutnie nie powinna mieć znamion traktowania instrumentalnego, bowiem aksjologiczne podmioty tej relacji myślą, czują, doświadczają, doznają i przeżywają poprzez empatyczne zrozumienie, co wyraża niejako istotę coachingu jako relacji paralelnej.

Ujmując temat filozoficznie, człowiek jest podmiotem wielowymiarowym obdarzonym wolną wolą, która pozwala mu decydować o sobie. W coachingu podmioty relacji świadomie rezygnują $\mathrm{z}$ wchodzenia $\mathrm{w}$ heglowską relację pan - niewolnik lub z pochyłego układu/zależności wyższości-niższości; odżegnują się również od wprowadzania w proces dyrektywnej atmosfery dominacji i podporządkowania ${ }^{11}$. Relacja coachingowa jest holistyczną, autentyczną, kongruentną, przejrzystą i dobrowolną - wspartą wartością zaufania - współzależnością podmiotów połączonych układem sojuszu. Podmioty tej relacji nie dokonują względem siebie moralnych osądów i ocen, w pełni uznając swoją odmienność.

Powstrzymując się przed wzajemnym ocenianiem, uczestnicy procesu coachingowego refleksyjnie wznoszą siebie na poziom dialogicznej relacji z pełnym bagażem doświadczeń i w pełni swej autentyczności ${ }^{12}$. Dlatego koniecznym warunkiem coachingowego dialogu staje się wiarygodność wsparta samoświadomością, „odwagą do bycia sobą; a także wolność od uprzedzeń, otwartość i osobiste zaangażowanie, które przekłada się na gotowość do budowania [przestrzeni - A.M.] intymności"13 w interaktywnej relacji.

11 Por. L.D. Czarkowska, Coaching jako konstruktywny dialog. Wprowadzenie, w: Coaching jako konstruktywny dialog, red. L.D. Czarkowska, Warszawa 2016, 9.

12 Por. tamże, 9-10.

13 Por. tamże, 10. 
Wielość możliwych definicji coachingu wskazuje na liczne związki łączące tę młodą, a zarazem niezwykle popularną współcześnie formę rozwojowej pracy z człowiekiem z filozofią; osobom parającym się zarówno filozofią, jak i coachingiem pozwala dostrzec możliwy wkład kontekstu filozoficznego w coaching jako dialogiczną metodę kształtowania/rozwoju zdolności samodzielnego myślenia i twórczego projektowania siebie w czasie.

Coaching jako dobrowolny, paralelny proces równowartościowych podmiotów, wymaga szczegółowego przejścia przez następujące obszary:

1. Obszar pytania o cel. W coachingu cel staje się azymutem, punktem na horyzoncie postrzeganym jako miejsce, którego wyznaczenie poprzedza uzgodnienie wiodącego tematu rozmowy; innymi słowy, w tym momencie procesu następuje zaakcentowanie głównego wątku dyskusji oraz przeprowadzenie względnej weryfikacji celu, to znaczy jego ujednoznacznienie lub doprecyzowanie. Doprecyzowanie to odbywa się przy zastosowaniu jednego $\mathrm{z}$ coachingowych akronimów konkretyzacji celu, np. modelu SMART, TARGET, KOMPAS, WARTO itp. W popularnym podręczniku profesjonalnego coachingu Jenny Rogers czytamy, iż faza „ustalania celów nakierowuje uwagę (...), wpływa na poprawę wyników (...) oraz oddziałuje na zmianę zachowania"14. Cel jako swoiście rozumiana oskoma, wyraża potrzeby i uściśla dążenia. Natomiast rozpoznanie własnych potrzeb, dążeń i możliwości uzmysławia nieświadome, działa motywująco i zapoczątkowuje procesy zmiany ${ }^{15}$. Autorka suponuje także, iż najłatwiej Klientowi osiągnąć cel niewymuszony i wyznaczony samodzielnie; ustalony w sposób możliwie najbardziej efektywny,

14 J. Rogers, dz. cyt., 123.

15 Tamże. 
angażujący wartości i wypracowany w oparciu o mocne strony Coachee.

2. Obszar rozpoznawczej eksploracji rzeczywistości, który wiąże się z pytaniem o fakty i liczby związane $z$ postawionym dylematem lub cele.

3. Obszar poszukiwania, badania i wyboru opcji/możliwości oraz rozpoznawania nieuświadomionych zasobów Coachee.

4. Obszar planowanych działań podejmowanych przez Coachee (What will you do?).

Każdy z wyróżnionych zakresów posiada swoją filozoficzną wymowę, dotyczy to także sfery (4) i sposobów praktycznej realizacji celów, które w refleksji filozoficznej nierzadko określa się mianem prakseologii jako teorii wszelakiego celowego działania. Genealogia tego pojęcia sięga czasów intelektualnej aktywności Alfreda V. Espinasa.

\section{PRAKSEOLOGIA I JEJ WYKORZYSTANIE W COACHINGU}

Prekursor prakseologii - francuski socjolog, myśliciel i intelektualista - Alfred V. Espinas, postrzega teorię sprawnego działania jako naukę o formach aktywności: systemach działania i czynnikach warunkujących intensyfikację sprawności tego działania; Espinas spiritus movens refleksji prakseologicznej - nazywa tę dyscyplinę drogą, a zarazem sposobem doskonalenia umiejętności praktycznych w toku dziejów.

Znaczną rolę w budowaniu architektoniki prakseologicznej odgrywa także rosyjski, wykształcony ekonomicznie, lekarz i filozof Aleksander Bogdanow (Malinowski), który teorię skutecznego działania identyfikuje z tektologią. Terminu 'prakseologia' oficjalnie nie stosuje, pozostając przy pierwotnej nazwie 'tektologia'. Nazywa ją nauką o strukturze i organizacji przedmiotów złożonych; dziedzina ta jest - jego zdaniem - działaniem związanym bezpośrednio $\mathrm{z}$ organizowaniem, formowaniem, nadawaniem czemuś kształtu lub 
wręcz przeciwnie: dezorganizowaniem, rozsadzeniem, dezintegracją, wprowadzeniem nieładu w celu przeprowadzenia koniecznej zmiany, ergo to rozprzęganie organizacji1 ${ }^{16}$. Nauka ta jest także postacią systematyzacji form organizowania poprzez „interwencję podmiotów działających" 17 .

Prakseologia jako tektologia (czyli prakseologia w formie inicjalnej lub prakseologia jako propedeutyka zarządzania systemami) opisuje wszelkie możliwe formy działania związanego z organizowaniem lub łączeniem w całość bogatego i skomplikowanego spiętrzenia zasobów. Efektem tego nawarstwienia zasobów są dopasowanie środków do założonego celu oraz koncentracja na optimum rezultatu.

Prakseologiczny styl myślenia znajduje swoich entuzjastów także w Polsce. Zarówno Aleksander Bogdanow (Malinowski), jak i Espinas odciskają swe trwałe piętno na systemie polskiego etyka, logika, metodologa nauk i teoretyka poznania Tadeusza Kotarbińskiego. Myśliciel ten zauważa, iż prakseologię „można nazwać również ogólną nauką organizacji, gdyż zmierza ona do wykrycia, sformułowania i uzasadnienia rad, które by wykazywały, jak najskuteczniej kształtować strukturę przedmiotów złożonych dla zapewnienia im trwałości i odporności na czynniki rozprzęgające w różnych sytuacjach i fazach rozwoju. Te rady mają zaś znajdować uzasadnienie w prawidłowościach rządzących powstawaniem, przemianami i utrzymywaniem lub rozprzęganiem struktur przedmiotów złożonych przystosowujących się do zmiennych okoliczności"18. W swoim programie filozofii Kotarbiński przyjmuje, że człowiek jako konkretny podmiot działający pragnie, by jego życie potoczyło się w pewien oczekiwany dla niego sposób, i z tego powodu postanawia podjąć określone działania.

Ten przedstawiciel szkoły lwowsko-warszawskiej nazywa prakseologię „rodzącą się nauką o sprawnej działalności ludzkiej”; także

16 Zob. T. Kotarbiński, Hasło dobrej roboty, Warszawa 1984, 22.

17 Tamże, 24.

18 Zob. tamże, 23. 
o sprawności, biegłości i potencjale wszelkich ludzkich działań. Prakseologia jako praksis jest w systemie Kotarbińskiego nauką dotyczącą usprawniania wszelkich ludzkich działań ${ }^{19}$. W ten sposób każdą dokonywaną przez człowieka czynność można klasyfikować spoglądając przez pryzmat skuteczności bądź gospodarności. O ile sprawność lub skuteczność oznaczają najczęściej robienie tego, co wydaje się na dany moment najlepszym środkiem do celu, o tyle identyfikowana z ekonomicznością - gospodarność, „zasadza się na tym, że operuje się w sposób oszczędny i wydajny posiadanymi zasobami miejsca, czasu, materiału, narzędzi i energii" 20 . Pojęcia prakseologiczne: metoda, narzędzie, środek i cel, to także podstawowe kategorie języka coachingu.

Klasyczna prakseologia, na którą składają się: 1) diagnoza - polegająca na zebraniu faktów; 2) prognoza - opierająca się na antycypacji (umiejętności przewidywania); 3) planowanie i programowanie a następnie 4) wykonanie jako praktyczna realizacja zaplanowanych teoretycznie działań oraz 5) ocena jako ewaluacja efektów procesu, jest także postacią metodologii ogólnej; nauką „o metodach jakiegokolwiek robienia czegokolwiek; nauką, która rozważa robotę z punktu widzenia skuteczności”21. Uszczegóławiając wywód, Kotarbiński proponuje trójdzielny rozdział prakseologii: jej pierwszy obszar dotyczy analizy pojęć wszelkich form działania celowego; obszar drugi obejmuje krytykę faktów pod względem ich sprawności, skuteczności, celowości i praktycznego użycia; natomiast obszar trzeci obejmuje część normatywno-doradczą skupiającą wskazówki działania (jako wykładnię teorii czynu) ${ }^{22}$.

Współmiernie do procesu coachingowego, zadania prakseologa zawierają się w sprawnym wyodrębnianiu i systematyzacji różnych

19 Zob. tamże, 22.

20 T. Kotarbiński, Prakseologia, część II, Wrocław 2003, 58.

21 Tamże, 58.

22 Tamże. 
form działania oraz próbie upraktycznienia tych działań. Czynności te powinny być poprzedzone i naznaczone dogłębną analizą rzeczywistości „tu i teraz”, która w ostateczności uwalnia refleksję nad sposobami obchodzenia się z obszarem zasobów i możliwości.

Podejście prakseologiczne spełnia się zatem także w wymiarze poznawania horyzontów wydolności i potencjału możliwości. Odkrycie nowej możliwości jest swego rodzaju - dotąd pomijaną, bądź niezauważaną - opcją wyjścia z sytuacji i osiągnięcia celu poprzez wykorzystanie wszelkich dostrzeżonych zasobów. W tym momencie warto jeszcze raz powtórzyć: $w$ relacji coachingowej przyjmuje się, że Podopieczny posiada wszystkie aktywa, które są mu potrzebne i niezbędne do osiągnięcia założonego celu. Osoba coachowana (Coachee) może być nieświadoma swoich zasobów, cech i przymiotów (resources), dlatego istota pracy Coacha w trakcie przeprowadzania procesu coachingowego tkwi w jego - niebezpośredniej - pomocy w samodzielnie podjętym przez Coachee wysiłku rozpoznawania i uświadamiania ich sobie; postępowaniu, w którym Podopieczny poprzez autorefleksję, zyskując świadomość własnego arsenału środków, odkrywa nierozpoznane dotąd ich możliwości osiągnięciu celu.

W praktyce coachingowej w takiej sytuacji aktywność Coacha wyraża się często w stawianiu pytań typu: kto może Ci w tym pomóc? Czego potrzebujesz, aby osiągnąć cel? Które kompetencje pomogą Ci w osiągnięciu celu? Tym sposobem Coach sprawia, że Klient sam buduje sobie bazę tego, co go naprawdę wspiera. Coaching zakłada, iż każdy człowiek posiada nieodkryty jak dotąd potencjał umożliwiający kształcenie (samorozwój). I chociaż „nie wszyscy posiadamy wszystkie wewnętrzne zasoby konieczne do osiągnięcia konkretnych celów, to wszyscy posiadamy zasoby wewnętrzne potrzebne do zdobywania dalszych zasobów tak wewnętrznych, jak i zewnętrznych"23.

Odnalezienie środków potrzebnych do realizacji wyznaczonego celu wymaga często zbadania domeny najgłębszych motywacji

23 R. Ready, K. Burton, NLP dla bystrzaków, tłum. z ang. C. Matkowski, Gliwice 2010, 39. 
Coachee. Poszukiwanie motywacji aktywizuje pracę na systemie wartości. Pełna klasyfikacja struktury aksjologicznej przedstawia zarówno konfiguracje wartości jedynie deklaratywnych, jak i faktycznie przez Coachee realizowanych. To sfera pasji, wydatkowania energii, spełnienia oraz świadomości możliwości zmiany otaczającego świata. To także sfera: (1) pytań granicznych (zapraszających do pogłębionej refleksji interrogacją typu: gdyby pozostał ci rok życia, co chciałabyś w tym czasie robić i kim chciałabyś być?); penetrujących kwerend o powody odczuwania największych wzruszeń; także zapytań o znaczenie życiowych zamiłowań, sympatii, upodobań czy inklinacji (życiowa pasja); (2) pytań o sprawy, na które Klient chętnie zużywa swoją energię; nowych perspektyw, których jest entuzjastą; pytań o to, czego nie może się doczekać; również, zapytań: o co w życiu ma ochotę walczyć?; do czego dąży? (energia);(3) pytań o spełnienie i motywy tego spełnienia, o znaczenie istotnych w życiu Klienta (Coachee) osiągnięć (to pytania wybrzmiewające w zdaniach: Jakie osiągnięcie byłoby dla Ciebie najistotniejsze?); (4) pytań o momenty życia pełnią życia; także pytań ostatecznych wybrzmiewających w słowach: co chciałbyś po sobie zostawić? (spełnienie); (5) nierzadko to także zakres refleksji nad kwestią inwestowania w resztę swojego życia; namysłu nad potrzebami serca; nad tym, co dla Coachee jest ważne $\mathrm{w}$ świecie lub godne podjęcia ryzyka (zmiana świata) ${ }^{24}$.

Każda z podjętych kwestii potencjalnie dotyka sfery marzeń Klienta. Zadaniem Coacha w trakcie procesu jest pomóc rozmówcy w samodzielnym, niewymuszonym, w pełni wolnym i otwartym zwerbalizowaniu tej sfery. Werbalizacji dokonujemy najczęściej stawiając tematyczne pytania, niejednokrotnie formułowane w trybie przypuszczającym: O czym marzysz? Co chciałbyś robić w życiu? Gdybyś miał nieograniczone środki, co byś zrobił? Jak wyglądałyby twoje marzenia, gdybyś rozciągnął je go granic możliwości? Czego chciałbyś spróbować $\mathrm{w}$ swoim życiu? Jakie nowe umiejętności

24 Zob. T. Stoltzfus, dz. cyt., 53. 
chciałbyś posiąść? Co stracisz, jeśli będziesz postępował zachowawczo? Co stracisz, jeśli nie będziesz dążył do spełniania swoich marzeń?25

Wewnętrzne pragnienia (marzenia/życzenia/pasje) należą do kategorii potencjalnych celów na przyszłość i jako takie często stanowią probierz tego, czego Coachee naprawdę łaknie w życiu; ku czemu się skłania, za czym tęskni, optuje lub o co zabiega ${ }^{26}$. Zwykle tę sferę chęci i pragnień w procesie coachingu dynamizujemy, kierując się $\mathrm{w}$ stronę realizacji niekłamanych, niepozorowanych, lecz konkretnych - w pełni świadomych, realnych i celowych działań

Budowanie „stanu zasobnego” nierzadko dokonuje się w praktyce kotwiczenia jako procesie rozbudzania i angażowania psychicznych stanów pozytywnych. Często dzieje się tak poprzez oddziaływanie bodźców zewnętrznych skutkujących wzmożoną chęcią podejmowania aktywności i wdrażania w życie zasadnych posunięć (działań). Kotwiczenie jest procesem, w wyniku którego dochodzi do „uzyskania trwałego powiązania pomiędzy bodźcem (kotwicą) a reakcją na ten bodziec"27. Uwzględniająca trzy etapy technika kotwiczenia (jako ustalania repertuaru wspomagających działanie czynników wzmacniających), obejmuje: (1) wyobrażenie sobie pozytywnego stanu pożądanego, (2) przywołanie konkretnego momentu bycia $\mathrm{w}$ tym stanie oraz (3) przeżywania go prawdziwie i szczerze ${ }^{28}$. Wyróżnione etapy służą osiąganiu oczekiwanego stanu pozytywnego. Kotwice to bodźce wyzwalające, które pomagają w zainicjowaniu i utrzymaniu optymalnego stanu bycia sobą. To kotwica (wzrokowa, dźwiękowa lub kinestetyczna) oraz sam proces kotwiczenia wspomaga procesy efektywnego uczenia się jako nabywania zdolności

25 Zob. tamże, 54.

26 Zob. tamże.

27 Por. Moc coachingu. Poznaj narzędzia rozwijające umiejętności i kompetencje osobiste, dz. cyt., 179.

28 R. Ready, K. Burton, dz. cyt., 144-145. 
czerpania $z$ własnych zasobów i nawiązywania cennych relacji z innymi ludźmi ${ }^{29}$.

W kontekście interaktywnego procesu coachingowego, który ujmuje rozmówcę (Klienta, Coachee, Podopiecznego) in toto, prakseologia jawi się więc jako forma ogólnej metodologii koncentrującej się na wyodrębnieniu i systematyzacji różnorodnych form działania. Cyk1 prakseologiczny w coachingu jest ścieżką holistycznego treningu, którą znamionują przenikające się wzajemnie, praktyczne działania.

\section{ZAKOŃCZENIE}

Podsumowując warto powtórzyć, iż coaching jest procesem eksponującym wymiar praksis, w którym podopieczny (Coachee) - po zarysowaniu głównego obszaru rozmowy, wyróżnieniu i sprecyzowaniu pożądanego celu - zyskuje pełniejszy/głębszy ogląd przeszkody, trudności lub trapiącego dylematu, a jednocześnie pozyskuje dla siebie cenną wiedzę dotyczącą tego, czego naprawdę chce. Uczestnik coachingu (Coachee), świadomy swoich zasobów i możliwości, czuje się zachęcony oraz wysoce zmotywowany do podjęcia praktycznych działań (action plan) najczęściej z już wyznaczonym konkretnie terminem realizacji pierwszego $\mathrm{z}$ nich ${ }^{30}$. W zaplanowaniu działań oraz ich skutecznej realizacji skrywa się istota prakseologii w coachingu.

To jednak, czy po zakończeniu procesu coachingowego Coachee podejmie - nakreślone podczas procesu - działania czy zatrzyma się wyłącznie w obszarze samej tylko spekulatywnej refleksji nad sobą, swoim życiem, bądź dylematem, który przepracował samodzielnie $\mathrm{w}$ ramach procesu, pozostaje Jego indywidualną decyzją.

29 Tamże, 147.

30 J. Starr, Podręcznik coachingu. Sprawdzone techniki treningu personalnego, tłum. z ang. A. Trzcińska, Warszawa 2015, 141-142. 


\section{BIBLIOGRAFIA}

Bennewicz M., Coaching, kreatywnośc, zabawa. Narzędzia rozwoju dla pasjonatów iprofesjonalistów, Olsztyn 2014.

Czarkowska L., Coaching jako konstruktywny dialog, Warszawa 2016.

Kotarbiński T., Hasto dobrej roboty, Warszawa 1984.

Kotarbiński T., Prakseologia, część II, Wrocław 2003.

Krupp S., Schoemaker P.J.H., Zwycięskie strategie. Jak liderzy tworzq przyszte sukcesy, tłum. $\mathrm{z}$ ang. M. Lipa, Warszawa 2016.

Moc coachingu. Poznaj narzędzia rozwijające umiejętności i kompetencje osobiste, red. M. Wilczyńska, M. Nowak, J. Kućka i in., Gliwice 2013.

O'Donovan G., A Coach's Story: revealing insights into life as a professional coach, Book Shaker 2011.

O’Neil M.B., Coaching dla kadry menadżerskiej. Sita i wrażliwość coacha w systemowym podejściu do problemów w zarzadzaniu, Poznań 2005.

Ready R., Burton K., NLP dla bystrzaków, tłum. z ang. C. Matkowski, Gliwice 2010.

Rogers J., Coaching. Podstawy efektywności, tłum. z ang. K. Konarowska, D. Porażka, Gdańsk 2010.

Rosinski P., Globalny coaching. Podejście zintegrowane, tłum. z ang. A. Niedzieska, P. Niedzieski, Warszawa 2011.

Starr J., Podręcznik coachingu. Sprawdzone techniki treningu personalnego, tłum. z ang. A. Trzcińska, Warszawa 2015.

Stoltzfus T., Sztuka zadawania pytań w coachingu. Jak opanować największq umiejętność coacha?, Cieszyn 2012.

\section{PRAXEOLOGY IN COACHING AS THE INTERACTIVE DISCOVERY PROCESS OF THE COACHEE'S RESOURCES AND POSSIBILITIES}

\footnotetext{
Abstract. Praxeology, the practice formulated by the French intellectual Alfred Espinas and Alexander Bogdanow (Malinowski), is the science of the efficiencies of human activity. As Tadeusz Kotarbiński and Tadeusz Pszczołowski argued, praxeology is a general methodology focused on separating and systematizing various forms of activities, as well as an attempt to improve and make them more practical. This assumes a certain analysis of reality and some way to handle it with available resources. Praxeology as a tectology strives to organize or merge the opulent and complicated accumulation of resources into a whole. This accumulation should be able to guarantee that the resources are adjusted to a certain goal to achieve the optimal result.
} 
This article stresses the relevance of praxeological arguments to the coaching process as supporting others in the self-discovery of their own abilities and resources to efficiently accomplish their own goals.

Keywords: praxeology, Tadeusz Kotarbiński, Alfred Espinas, Aleksander Bogdanow, tectology, interactive process, dialogue, coaching, coachee

\section{AnNa Musiot}

anna.musiol@us.edu.pl

Uniwersytet Śląski w Katowicach, Wydział Nauk Społecznych, Instytut Filozofii

Bankowa 11, 40-007 Katowice

DOI: 10.21697/spch.2018.54.3.16 